\title{
An Investigation of Prospective Teachers' Attitudes Towards National Parks and Views on Ecology-Based Environmental Education
}

\author{
Hilmi Demirkaya (Corresponding author) \\ Faculty of Education, Akdeniz University \\ Pınarbaşı, Konyaaltı, Antalya, 07070, Turkey
}

Tel: 90-242-310-6625Ｅ-mail: hdemirkaya@akdeniz.edu.tr

Dilek Erduran Avc1

Faculty of Education, Burdur Mehmet Akif Ersoy University

İstiklal Yerleşkesi, Burdur, 15100, Turkey

Tel: 90-248-213-4000Ｅ-mail: derduran@mehmetakif.edu.tr

Hasan Genç

Faculty of Education, Burdur Mehmet Akif Ersoy University

İstiklal Yerleşkesi, Burdur, 15100, Turkey

Tel: 90-248-213-4000 E-mail: hagetr@yahoo.com

Huriye Deniş Çeliker

Faculty of Education, Burdur Mehmet Akif Ersoy University İstiklal Yerleşkesi, Burdur, 15100, Turkey

Tel: 90-248-213-4000Ｅ-mail: huriyedenis@mehmetakif.edu.tr

\section{Bekir Yildırım}

Burdur Food Agriculture and Livestock Vocational School of Higher Education Burdur Mehmet Akif Ersoy University, İstiklal Yerleşkesi, Burdur, 15100, Turkey

Tel: 90-248-213-2271_E-mail: bytr33@yahoo.com 
Didem Gamze Genç

Faculty of Education, Burdur Mehmet Akif Ersoy University

İstiklal Yerleşkesi, Burdur, 15100, Turkey

Tel: 90-248-213-4000Ｅ-mail: dggenc.bsg@gmail.com

Orhan Ünal

Faculty of Education, Ondokuz Mayıs University

Kurupelit Campus, Samsun, 55139, Turkey

Tel: 90-362-312-5941Ｅ-mail: orhan.unal@omu.edu.tr

\author{
Ülkü Tuğçe Çal \\ Faculty of Education, Akdeniz University \\ Pınarbaşı, Konyaaltı, Antalya, 07070, Turkey
}

Tel: 90-242-227-4667_E-mail: tugcecal@akdeniz.edu.tr

Received: July 19, 2020 Accepted: August 16, 2020 Published: August 23, 2020

doi:10.5296/jei.v6i2.17379 URL: https://doi.org/10.5296/jei.v6i2.17379

This research was supported by The Scientific Research Projects Coordination Unit of Akdeniz University, Project Number: 3796.

\begin{abstract}
In this study, it was aimed to determine prospective social studies and elementary education teachers' attitudes towards national parks and views on ecology-based environmental education. In this study, which was conducted following the stated purpose, an educational practice was carried out in Termessos National Park (Antalya) for two days in 2018 with a total of 26 prospective teachers enrolled at faculty of education at Akdeniz University, of whom 11 from social studies education and 15 from elementary education. In the study, in which a mixed research design was employed, the "Attitude Towards National Parks Scale" developed by Deniş, Genç, and Demirkaya (2008) was used as a data collection tool. Pretest and posttest analyses of the data were conducted using SPSS to determine the effect of ecology-based environmental education given in the specified national park on the prospective teachers' attitudes towards national parks. In the qualitative part of the study, the
\end{abstract}


participants' views on ecology-based environmental education were elicited through interviews conducted before and after the practice education with the help of the "interview form for ecology-based environmental education," which was developed by the researchers. The data obtained were subjected to content analysis, which is one of the qualitative analysis techniques. The results revealed that the practice "Ecology-based Environmental Education in a National Park" positively affected the prospective teachers' attitudes towards national parks and contributed positively to their views on ecology-based environmental education.

Keywords: Prospective teacher, Attitude towards national parks, Environment, Ecology-based environmental education, Mixed-method

\section{Introduction}

Since their very existence on earth, human beings have benefited from the natural environment, cultivated lands, and reinforced their rule over nature continuously and increasingly with the help of their knowledge and technological advancements. The natural environment has been cultivated for centuries by human beings without any future concerns, and all the riches of nature have been utilized as if they were endless (Deniş, 2007; Deniş \& Genç, 2010, p. 10). Atasoy (2006) defines the environment as a spatial setting with which living begins are connected through life bonds and interact. He argues that artificial and natural changes to the environment will inevitably affect all living creatures living in that environment. While the human impact on the natural environment was limited until the Industrial Revolution, people have been ruining the natural environment since then. Supporting investors to accelerate production and consumption cycles has increased the pressure on soil cultivation, which has influenced the deterioration of the natural environment (Demirkaya \& Ünal, 2018; Ayvaz Öztürk, 2019). Today, advances in technology have advanced people's opportunities to intervene in nature as well, which has become a significant pressure on the environment.

Environmental damage and degradation through human activities were not ignored at first due to nature's ability to renew itself, or it was believed that nature could cope with them. However, over time, the increasing intensity of quantitative and qualitative pressures on the environment has exceeded beyond nature's self-renewal ability and initiated a rapid deterioration. People have only been able to recognize such deterioration with the distortion in their fundamental needs: air and water. It has been noticed that some species face the danger of extinction, and mass human deaths and permanent diseases occur due to the distortion in air and water. Human beings have only been able to become aware of the importance of environmental problems when they have realized that the environment where they eat, drink, and live poses a threat to their own health (Demirkaya, 2006).

The pressure of human beings on nature, the ever-increasing world population, the rapid consumption of natural elements, and the unplanned urbanization have accelerated the process of distortion in natural balance. Such negativities that occur in the natural environment have prompted people to take some measures individually or in groups (Güler, 2009). Over the historical course of such NGO movements of nature-sensitive people, it is noteworthy that their actions are mostly concentrated around several meetings. The first 
comprehensive action on environmental protection in the international platform was initiated by the United Nations (UN). The first meeting was held in Stockholm in 1972 with the theme of 'Human Environment.' The meeting emphasized the cooperation of countries and institutions at the international level regarding the further steps for nature. In the Tbilisi conference, which was held at the state level in 1977, effective strategies were developed on environmental education, and necessary studies were carried out for the implementation of such strategies in countries to prevent environmental problems. At the Rio meeting in 1992, active initiatives and some concrete decisions were taken regarding environmental education. Following the Rio Conference in 1994, initiatives on environmental education that started with the 'Seventh Five Year Development Plan' published by The Undersecretariat of State Planning Organization of Turkey were improved on various platforms (Güler, 2007).

Today, every country has decided to act together against environmental problems since they have realized that it is not enough to protect their own national boundaries but that the world ecosystems should be protected as a whole. For this reason, areas rich especially in terms of biological diversity and natural and cultural resource values, such as national parks, are protected with conservation status (Yalınkılıç \& Yenilmez Arpa, 2005, as cited in Deniş, Genç, $\&$ Demirkaya, 2008). Protected areas are vital for the sustainability of species and ecosystems that are at risk regarding the protection of biological diversity. In addition to such functions, protected areas also host cultural and economic functions, such as rural development, recreation, eco-tourism, and education-research. While the primary purpose of protection was initially to bring protectionist approaches to these areas, they are now characterized by sustainable resource management. The concept of sustainable development was the central theme of the 5th World Congress on National Parks and Protected Areas (Kuvan, 2005).

According to the 3rd Article of the National Parks Law, an area determined to have national park characteristics can be declared as a national park area upon the decision of the Council of Ministers upon the proposal of the Ministry of Environment and Forestry, with the positive remarks of the ministries of national defense, zoning and settlement, and culture and tourism, and the remarks of other relevant ministries, if necessary (Demirel, Sarıkoç, Özdemir, \& Pirselimoğlu, 2005). Turkey has a total of 40 national parks with a variety of geographical and natural features. The determination, management, protection, and improvement of national parks are under the responsibility of the Ministry of Environment and Forestry, and the ministry also has the task of opening research and training centers within its jurisdiction (Resmi Gazete, 2003).

The quantity and quality of natural resources have a critical place in the development of countries. Every country with a high-level awareness of nature develops various strategies for the conservation and sustainable operation of its natural resources. In addition, it can be challenging to explain the importance of conservation and sustainability of living species without a defined economic value. In contrast, the importance of protecting resources with economic value can be easily understood (Çepel, 1992). Çepel (2003) defined biodiversity as living worlds consisting of living populations rich in numbers and species, having diverse functions from living species with genetic differences, and spreading to various ecosystems. 
The socio-economic characteristics and educational attainments of residents around a national park can affect their perceptions of responsibility towards national parks. There are various studies concluding that education increases the awareness and protective emotions of people for protected areas. Some studies have also investigated the effect of income level on people's attitudes towards national parks. While people with high socio-economic status have purchasing power, others can be more dependent on natural resources. It is thought that people show more positive and helpful attitudes towards nature as their educational attainments and socio-economic statuses advance (Lam, 2004).

A national park is defined as a special area without the human impact that has scientific value in terms of history, aesthetics, and natural environment, and where scientific studies are carried out (Atalay, 2004). National parks can be used as a learning environment for students and even individuals of all ages. National park visitors can satisfy their curiosity by directly contacting real objects. Different tools can be employed in environmental education while trying to understand human interaction with the environment and to gain environmental awareness to society (Köksal, 2005). Today, national parks, protected natural areas, and green spaces in cities can be considered natural laboratories and evaluated for educational purposes in environmental education (Atik \& Tokgöz, 2005).

The recent trend of international tourists has focused on activities in national parks. Developing positive attitudes towards national parks is at least as necessary as the creation of national parks. For this reason, it is recognized that tourists especially perceive such areas as eco-tourism areas (Bodnar, 2004).

Human is a psycho-social being that can raise its level of knowledge, culture, and education. Education and socialization start within the family, take shape in the school, and continue through the life of an individual. Environmental awareness in the individual is also primarily completed within the family and school environment. Namely, various variables, such as family, education, life, and working environment, have a substantial role in the formation and emergence of environmental attitudes. It is natural to expect individuals who have diverse socio-economic, cultural, and educational backgrounds to adopt different attitudes towards the environment (Atasoy, 2006; Genç, Demirkaya, \& Karasakal, 2010).

One of the critical tasks of societies for a sustainable life is to equip children with attitudes, values, knowledge, and skills needed to protect the environment. Environmental education has an essential place in satisfying such needs. Environmental education has moral and operational aspects, and it should be a way of life rather than basic knowledge to be learned (Davis, 1998). Environmental education also aims to help individuals perceive ecological balance and their roles in this balance, gain a perspective on how they can live in harmony with the earth, and acquire the skills required by active and responsible participation (Erol \& Gezer, 2006).

Children are required to receive regular environmental education outside of school settings within an effective and efficient program. As people are aware of the functioning of ecosystems and the positive and negative impacts of human activities on the sustainability of these systems, they develop more conscious and responsible behaviors towards nature. The 
true meaning of the natural environment can be learned through direct interaction with it; thus, people will approach nature empathically. In line with all these given, environmental education is only meaningful when it is done in a natural environment since it increases the interest in and empathy to nature (Ozaner, 2004; Güler, 2009).

Ozaner (2004) defines environmental education as the learning of the language of nature and claims that even a brief environmental education, which is carried out in a natural environment, will contribute a lot to the participants' perspectives on the universe, life, and events. Ecology-based environmental education is one of the best teaching approaches that individuals can practice what they have learned about the environment and science. Well-planned nature education will enable individuals to acquire the ability to understand nature and to adopt positive attitudes and values towards nature and the environment, as well as permanent learning (Thoe \& Lin, 2006).

High-quality environmental education for students is closely related to how they see themselves interacting with the natural world during their real-life experiences. Experiences in nature help students to increase their self-confidence and to develop empathic approaches to nature. The knowledge and skills they acquire are key for their self-perceptions, respect for the natural environment, and its protection. Therefore, students should be freed to explore the natural world directly and to learn by their own experiences after the necessary security measures are taken (Genç, Demirkaya, \& Karasakal, 2010). Accordingly, teachers who will plan learning opportunities out-of-school environments, such as natural areas, parks, and gardens, become one of the most critical stakeholders of environmental education. Teachers can help students develop and promote their environmental knowledge and awareness based on their curiosity and interest in nature. When a teacher lacks environmental sensitivity and awareness, it is not likely to teach about the environment to its students (Malone \& Tranter, 2003; Güler, 2009).

This study aimed to put prospective teachers' theoretical knowledge into practice in a national park environment. Prospective teachers will also learn how to make learning enjoyable through learner-centered, active learning methods while putting their theoretical knowledge into practice in the natural environment. Although various education programs have recently been conducted in protected areas to foster the protection of nature and environment, they are outnumbered and have inadequate widespread impact. This study explored prospective social studies and elementary education teachers' attitudes towards national parks and views on ecology-based environmental education.

\subsection{Aim of the Study}

This study aimed to reveal prospective social studies and elementary education teachers' attitudes towards national parks and to examine their views on ecology-based environmental education.

The research questions determined by the purpose of the research are as follows:

What is the effect of the practice ecology-based environmental education in a national park on the prospective teachers' attitudes towards national parks? 


\section{Macrothink}

What are the pre-practice views of the prospective teachers on ecology-based environmental education?

What are the post-practice views of the prospective teachers on ecology-based environmental education?

\section{Method}

\subsection{Design of the Study}

A "mixed-method" was adopted in this study since it was needed to collecting both quantitative and qualitative data due to the nature of the research problem. The current study employed an embedded design, in which quantitative and qualitative data are compiled simultaneously or sequentially and analyzed independently (Buldur \& Doğan, 2017). A single group pretest-posttest design was utilized to reveal the effect of the practice ecology-based environmental education in a national park on the prospective teachers' attitudes towards national parks. In this design, relevant dependent variables are analyzed as a result of the same test applied to a single group before and after an experimental procedure (Sönmez \& Alacapınar, 2011). Accordingly, only one experimental group was created in this study. The symbolic view of this design is given in Table 1 .

Table 1. Symbolic View of Single Group Pretest-Posttest Design

\begin{tabular}{|l|l|l|l|l|}
\hline G1 & R & O1.1 & X & O1.2 \\
\hline
\end{tabular}

Note. G: Experiment group (The group with which time capsule activity was performed); R: Random assignment; X: Independent variable; O1.1: Pretest; O1.2: Posttest.

The qualitative data of the research were collected through interview forms. The research stages are symbolically shown in Figure 1.

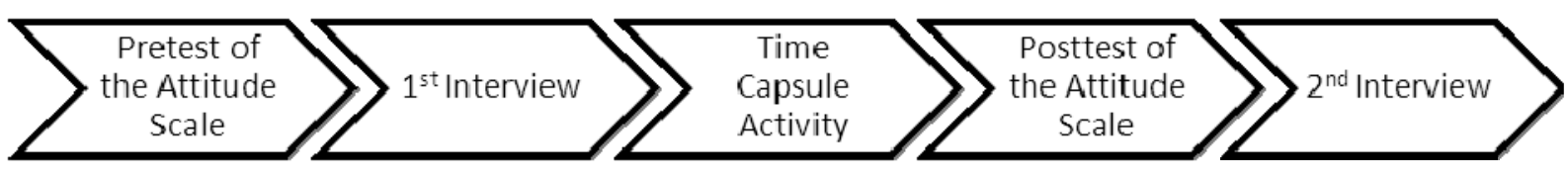

Figure 1. Stages in the study

\subsection{Sample}

The research was carried out with prospective social studies and elementary education teachers in the Termessos National Park, which is located within the borders of Antalya province, in the 


\section{Macrothink}

2018 summer. The sample was composed of 26 prospective teachers selected from the faculty of education at Akdeniz University through random sampling.

Table 2. Distribution of prospective teachers by departments

\begin{tabular}{|l|l|l|l|}
\hline \multicolumn{2}{|l|}{ Department } & N & \% \\
\hline \multirow{2}{*}{} & Social Studies & 11 & 42.3 \\
\cline { 2 - 4 } & Elementary Education & 15 & 57.7 \\
\cline { 2 - 4 } & Total & $\mathbf{2 6}$ & $\mathbf{1 0 0 . 0}$ \\
\hline
\end{tabular}

The study included a total of 26 prospective teachers, of whom 11 were from social studies education and 15 from elementary education.

Table 3. Distribution of prospective teachers by gender

\begin{tabular}{|c|l|l|l|}
\hline \multicolumn{2}{|l|}{ Gender } & N & \% \\
\hline \multirow{3}{*}{} & Female & 18 & 69.2 \\
\cline { 2 - 4 } & Male & 8 & 30.8 \\
\cline { 2 - 4 } & Total & $\mathbf{2 6}$ & $\mathbf{1 0 0 . 0}$ \\
\hline
\end{tabular}

Among the participants, 18 were females, and 8 were males.

Table 4. Whether to visit a national park before the research visit

\begin{tabular}{|l|l|l|l|}
\hline \multicolumn{2}{|c|}{ A Visit to a National Park Before } & N & $\%$ \\
\hline \multirow{2}{*}{} & Yes & 6 & 23.1 \\
\cline { 2 - 4 } & No & 20 & 76.9 \\
\cline { 2 - 4 } & Total & $\mathbf{2 6}$ & $\mathbf{1 0 0 . 0}$ \\
\hline
\end{tabular}

While 6 of the participants had been to a national park before, 20 had never before. It was determined that these 6 participants had been to a national park for picnic purposes. 
Table 5. Distribution of prospective teachers' views on to what extent a nearby located national park is cared about

\begin{tabular}{|l|l|l|l|}
\hline \multicolumn{2}{|l|}{ Caring About a Nearby Located National Park } & N & \% \\
\hline \multirow{4}{*}{ Considerably } & 1 & 3.8 \\
\cline { 2 - 4 } & Properly & 10 & 38.5 \\
\cline { 2 - 4 } Barely & 12 & 46.2 \\
\cline { 2 - 4 } & Never & 3 & 11.5 \\
\cline { 2 - 4 } & Total & $\mathbf{2 6}$ & $\mathbf{1 0 0 . 0}$ \\
\hline
\end{tabular}

Table 5 shows the distribution of the participants' views on to what extent authorities and people care about a nearby located national park. Twelve participants thought that it is barely cared about; 10 thought that it is moderately cared about; 3 thought that it is never cared about; and 1 thought that it is considerably cared about.

\subsection{Data Collection Tools}

In the study, the Attitude Towards National Parks Scale (pretest-posttest) and the interview forms (first and second forms) for the practice ecology-based environmental education were used as data collection tools.

\subsubsection{The Attitude Towards National Parks Scale}

The two-factor 33-item "Attitude Towards National Parks Scale," developed by Deniş, Genç, and Demirkaya (2008), was used to measure the prospective teachers' attitudes towards national parks. The Cronbach's Alpha internal consistency coefficient for the first sub-scale was 0.88 , and it was 0.75 for the second sub-scale. As a result of the factor analysis, 33 items were left with positive and negative statements after 17 items were excluded from the scale.

As the reliability and validity studies of the 5-point Likert-type scale were done before by the developers, there was no need for a pilot study on the scale in this research. The scale was administered directly to 26 prospective teachers in the experiment group, and the participants were asked to tick one of the boxes among "strongly agree (5)", "agree (4)", "neutral (3)", "disagree (2)," and "strongly disagree (1)" across each item. The participants were reminded not to leave missing items on the scale and to tick only one option. The responses of the participants were transferred to SPSS 22.0, and the negative items on the scale were reversely scored. All the analyses were conducted on SPSS 22.0.

\subsubsection{The Interview Forms for Ecology-Based Environmental Education}

The forms were created by the researchers to elicit the views of prospective teachers on ecology-based environmental education. There are 10 open-ended interview questions in the first and second interview forms to be asked to prospective teachers in the experiment group. The analysis findings for each question were given in the findings section of the study. 


\section{Ml Macrothink}

The researchers paid strict attention to the collected data to be consistent and meaningful to ensure the validity of the data analysis process. The interview forms used in the study were created based on the literature review. Moreover, expert opinions were consulted, and a few trial interviews were performed to obtain the final versions of the forms. In addition, the validity and reliability of the data analysis were fostered by the help of a science education specialist, a social studies education specialist, and a measurement and evaluation specialist during the coding and theme identification processes.

Experts encoded the interview records that they had examined separately. Each question that was asked to participants was considered as a theme. Subthemes were obtained from the codes that experts found out. Thus, the rate of harmony between the approaches was determined. Reliability percentage was computed in compliance with the formula of Miles and Huberman coding reliability, which is (Reliability Percentage $=$ Agreement/(Total Agreement + Disagreement), and it is expected to obtain at least $80 \%$ reliability (Miles \& Huberman, 2004). General conceptual coding reliability was determined as 93 in the study. In this case, it has been accepted that the result of the study is at a reliable level.

\subsection{Data Analyses}

In this study, the data were analyzed in two stages. The first one was related to the Attitude Towards National Parks Scale administered to the experimental group as pretest and posttest. In the analysis of the data, arithmetic means (M) and standard deviations (SD) were given. Independent samples t-test were used for repeated measurements. The significance level was accepted as $\mathrm{p}<.05$ in all statistical analyses. In the second stage, the content analysis technique was used to analyze the qualitative data obtained through the first and second interview forms.

The data obtained through interviews prior to the practice ecology-based environmental education were analyzed with the content analysis technique. The participants were coded from R1 to R26. Among the subjects, the codes from R1 to R11 were given to prospective social studies teachers, while prospective elementary education teachers were given the codes from R12 to R26.

\subsection{Study Procedure}

The study was carried out in the following order:

(1) Firstly, the ethical committee approval was obtained from Akdeniz University to conduct the study and practice education. The reason why Termessos National Park was selected as the practice area was that it is located close to both the researchers and the participants and that it is available for ecology-based environmental education. At this stage, the permission for the practice education was obtained from the Ministry of Forestry and Water Affairs, General Directorate of Nature Conservation and National Parks, $6^{\text {th }}$ Regional Directorate, Antalya Branch Directorate. In addition, relevant permissions were also obtained from the Ministry of Culture and Tourism, Antalya Provincial Directorate of Culture and Tourism. 
(2) Eleven prospective social studies teachers and 15 prospective elementary education teachers were identified through random sampling.

(3) The practice education was carried out in October 2018.

(4) Semi-structured interview questions were generated to be asked to the experiment group before and after the practice education.

(5) The opinions of academics and experts working in the relevant fields were consulted regarding the interview questions.

(6) The steps to be followed in the office and Termessos National Park during the practice education were identified. The expert opinions were consulted for these steps, and a list for "practice education stages" was generated, taking into account feedback and corrections from the experts.

(7) The attitude scale was preliminarily administered as a pretest to the participants to determine to what degree the ecology-based environmental education, to be practiced as an independent variable, would affect the attitudes of the participants towards national parks.

(8) The participants were recruited to the first semi-structured interviews on ecology-based environmental education before the practice.

(9) The researchers held a meeting with the prospective teachers for 2 class hours before the practice to eliminate the negative attitudes that might occur during the practice.

(10) After the meeting, the Termessos National Park was visited, and the first-day practice was carried out between 09:00 and 17:00 in the area, which was previously identified with relevant feasibility studies by the researchers. The second practice was carried out between 09:00 and 17:00 in the same place after 15 days from the first practice.

(11) The participants were recruited to the second semi-structured interviews on ecology-based environmental education after the second practice.

(12) Finally, the attitude scale was administered to the experiment group as a posttest following the practice ecology-based environmental education.

\section{Results}

This section included the findings, reached as a result of the data analyses, and the interpretations of these findings.

The normality of the data was checked before the statistical analyses. The table below summarizes the results of normality tests performed on the pretest and posttest scores on the Attitude Towards National Parks Scale. 
Table 6. Normality values of the pretest and posttest scores on the attitude scale

\begin{tabular}{|l|l|l|l|l|}
\hline Tests & Groups & Shapiro-Wilk & Skewness & Kurtosis \\
\hline \multirow{3}{*}{ Pretest } & Social Studies & .748 & .080 & -.904 \\
\cline { 2 - 5 } & Elementary Education & .062 & 1.223 & 1.135 \\
\hline \multirow{3}{*}{ Posttest } & Social Studies & .887 & .686 & .578 \\
\cline { 2 - 5 } & Elementary Education & .004 & 1.718 & 2.636 \\
\hline
\end{tabular}

As in Table 6, the normality assumption could not be satisfied since the skewness and kurtosis values were not in the range of +1.5 to -1.5 (Tabachnick \& Fidell, 2015). In addition, the Shapiro-Wilk value was found to be significant for the posttest scores of prospective elementary education teachers; that is, the data did not normally distribute $(\mathrm{p}<0.05)$.

\subsection{Findings Regarding the First Research Question}

\subsubsection{Comparison of the Participants' Pretest Scores on the Attitude Scale by Gender}

The Mann Whitney U-Test analysis was conducted to examine whether the prospective teachers' pretest scores on the attitude scale differed significantly by gender. The absence of a significant relationship between the pretest scores was an essential determinant of the progress of the study. The result of the analysis is given below:

Table 7. U-Test results for the participants' pretest scores on the attitude scale by gender

\begin{tabular}{|l|l|l|l|l|l|}
\hline Gender & N & Mean rank & Sum of ranks & U & p \\
\hline Female & 18 & 14.94 & 269.00 & \multirow{2}{*}{46.00} & .148 \\
\hline Male & 8 & 10.25 & 82.00 & & \\
\hline
\end{tabular}

The U-test results for pretest scores on the "Attitude Towards National Parks Scale" are given in Table 7. Accordingly, prior to the "Practice Ecology-based Environmental Education," it was determined that the prospective teachers' pretest scores on the "Attitude Towards National Parks Scale" did not differ significantly by gender $(U=46.00, p>0.05)$. Considering the mean ranks, it was found that prospective female teachers had higher scores on the "Attitudes Towards National Parks Scale" than their male counterparts. 


\section{Macrothink}

3.1.2 Comparison of the Participants' Posttest Scores on the Attitude Scale by Gender

Table 8. U-Test results for the participants' posttest scores on the attitude scale by gender

\begin{tabular}{|l|l|l|l|l|l|}
\hline Gender & $\mathbf{N}$ & Mean rank & Sum of ranks & $\mathbf{U}$ & $\mathbf{p}$ \\
\cline { 1 - 5 } Female & 18 & 14.64 & 263.50 & \multirow{2}{*}{51.500} & \multirow{2}{*}{.254} \\
\cline { 1 - 5 } & 8 & 10.94 & 87.50 & & \\
\hline
\end{tabular}

The U-test results for posttest scores on the "Attitude Towards National Parks Scale" are given in Table 8. Accordingly, it was determined that the posttest scores of the prospective teachers, who attended the "Practice Ecology-based Environmental Education," on the "Attitude Towards National Parks Scale" did not differ significantly by gender ( $U=51.500$, $p>0.05$ ). Considering the mean ranks, it was found that prospective female teachers had higher scores on the "Attitude Towards National Parks Scale" than their male counterparts.

3.1.3 Comparison of the Participants' Pretest Scores on the Attitude Scale by Teaching Field

Table 9. U-Test results for the participants' pretest scores on the attitude scale by teaching field

\begin{tabular}{|l|l|l|l|l|l|}
\hline Teaching Field & N & Mean rank & Sum of ranks & U & p \\
\cline { 1 - 5 } Social Studies & 11 & 16.91 & 186.00 & \multirow{2}{*}{45.00} & \multirow{2}{*}{.051} \\
\cline { 1 - 3 } Elementary Education & 15 & 11.00 & 165.00 & & \\
\hline
\end{tabular}

The U-test results for pretest scores on the "Attitude Towards National Parks Scale" are given in Table 9. Accordingly, prior to the "Practice Ecology-based Environmental Education," it was determined that the prospective teachers" pretest scores on the "Attitude Towards National Parks Scale" did not differ significantly by teaching field $(U=45.00, p>0.05)$. Considering the mean ranks, it was found that prospective social studies teachers had higher scores on the "Attitude Towards National Parks Scale" than prospective elementary education teachers. 
3.1.4 Comparison of the Participants' Posttest Scores on the Attitude Scale by Teaching Field

Table 10. U-Test results for the participants' posttest scores on the attitude scale by teaching field

\begin{tabular}{|l|l|l|l|l|l|}
\hline Teaching Field & $\mathbf{N}$ & Mean rank & Sum of ranks & U & p \\
\hline Social Studies & 11 & 14.77 & 162.50 & \multirow{2}{*}{68.500} & \multirow{2}{*}{.467} \\
\hline Elementary Education & 15 & 12.57 & 188.50 & & \\
\hline
\end{tabular}

The U-test results for posttest scores on the "Attitude Towards National Parks Scale" are given in Table 10. Accordingly, it was determined that the posttest scores of the prospective teachers, who attended the "Practice Ecology-based Environmental Education," on the "Attitude Towards National Parks Scale" did not differ significantly by teaching field ( $=$ $68.500, p>0.05)$. Considering the mean ranks, it was found that prospective social studies teachers had higher scores on the "Attitude Towards National Parks Scale" than prospective elementary education teachers.

\subsubsection{Prospective Social Studies Teachers' Pretest and Posttest Scores on the Attitude Scale}

Wilcoxon Signed-Ranks Test was conducted to examine whether there was a significant relationship between prospective social studies teachers' pretest and posttest scores on the Attitude Towards National Parks Scale. The results of the test are summarized in the table below.

Table 11. The results of the Wilcoxon Signed-Ranks Test for prospective social studies teachers' pretest and posttest scores

\begin{tabular}{|l|l|l|l|l|l|}
\hline Tests & N & Mean rank & Sum of ranks & $\mathbf{z}$ & $\mathbf{p}$ \\
\hline Pretest & 5 & 4.50 & 22.50 & & \\
\hline Posttest & 6 & 7.25 & 43.50 & -.937 & .349 \\
\hline Equal & 0 & & & & \\
\hline
\end{tabular}

Note. $*$ Based on negative ranks $* \mathrm{p}>0.05$.

It was found that prospective social studies teachers' mean pretest score $(\bar{X}=4.50)$ on the Attitude Towards National Parks Scale was lower than their mean posttest score $(\bar{X}=7.39)$. The results of the analysis revealed there was no significant relationship between prospective social studies teachers' mean pretest and posttest scores; therefore, it can be asserted that ecology-based environmental education did not have a significant positive effect on their attitudes towards national parks. 


\section{I Macrothink}

Journal of Educational Issues

ISSN 2377-2263

2020, Vol. 6, No. 2

3.1.6 Prospective Elementary Education Teachers' Pretest and Posttest Scores on the Attitude Scale

Wilcoxon Signed-Ranks Test was conducted to examine whether there was a significant relationship between prospective elementary education teachers' pretest and posttest scores on the Attitude Towards National Parks Scale. The results of the test are summarized in the table below.

Table 12. The results of the Wilcoxon Signed-Ranks Test for prospective elementary education teachers' pretest and posttest scores

\begin{tabular}{|l|l|l|l|l|l|}
\hline Tests & $\mathbf{N}$ & Mean rank & Sum of ranks & $\mathbf{z}$ & $\mathbf{p}$ \\
\hline Pretest & 4 & 8.38 & 33.50 & & \multirow{2}{*}{-1.506} \\
\cline { 1 - 4 } Post & 11 & 7.86 & 86.50 & & \\
\hline Equal & 0 & & & & \\
\hline
\end{tabular}

Note. ${ }^{*}$ Based on negative ranks $* \mathrm{p}>0.05$.

Table 12 shows that prospective elementary education teachers' mean pretest score $(\bar{X}=8.38)$ on the Attitude Towards National Parks Scale was lower than their mean posttest score $(\bar{X}=$ 7.86). The results of the analysis revealed there was no significant relationship between prospective elementary education teachers' mean pretest and posttest scores; thus, it can be suggested that ecology-based environmental education did not have a significant positive effect on their attitudes towards national parks.

3.1.7 Comparison of the Participants' Pretest Scores on the Attitude Scale by Whether to Visit a National Park Before

Table 13. U-Test results for the participants' pretest scores on the attitude scale by whether to visit a national park before

\begin{tabular}{|l|l|l|l|l|l|}
\hline A Visit to a National Park Before & N & Mean rank & Sum of ranks & U & p \\
\hline Yes & 6 & 15.25 & 91.50 & \multirow{2}{*}{49.500} & .523 \\
\hline No & 20 & 12.98 & 259.50 & & \\
\hline
\end{tabular}

The U-test results for pretest scores on the "Attitude Towards National Parks Scale" are given in Table 13. Accordingly, prior to the "Practice Ecology-based Environmental Education," it was determined that the prospective teachers' pretest scores on the "Attitude Towards National Parks Scale" did not differ significantly by whether to visit a national park before (U $=49.500, \mathrm{p}>0.05)$. Considering the mean ranks, it was found that pretest scores of the 


\section{Macrothink}

Journal of Educational Issues

ISSN $2377-2263$

2020, Vol. 6, No. 2

prospective teachers who had visited a national park before the research visit were higher than those who had not.

3.1.8 Comparison of the Participants' Posttest Scores on the Attitude Scale by Whether to Visit a National Park Before

Table 14. U-Test results for the participants' posttest scores on the attitude scale by whether to visit a national park before

\begin{tabular}{|l|l|l|l|l|l|}
\hline A visit to a National Park Before & N & Mean rank & Sum of ranks & U & p \\
\hline Yes & 6 & 15.33 & 92.00 & \multirow{2}{*}{49.000} & \multirow{2}{*}{.503} \\
\cline { 1 - 5 } No & 20 & 12.95 & 259.00 & & \\
\hline
\end{tabular}

The U-test results for posttest scores on the "Attitude Towards National Parks Scale" are presented in Table 14. Accordingly, it was determined that the posttest scores of the prospective teachers, who attended the "Practice Ecology-based Environmental Education," on the "Attitude Towards National Parks Scale" did not differ significantly by whether to visit a national park before $(U=49.000, p>0.05)$. Considering the mean ranks, it was found that pretest scores of the prospective teachers who had visited a national park before the research visit were higher than those who had not.

3.1.9 Comparison of the Participants' Pretest Scores on the Attitude Scale by to What Extent a Nearby Located National Park Is Cared About

Table 15. The results of the Kruskal-Wallis test for the participants' pretest scores on the attitude scale by to what extent a nearby located national park is cared about

\begin{tabular}{|l|l|l|l|l|l|}
\hline Caring about a nearby located national park & $\mathbf{N}$ & Mean rank & DF & $\chi^{2}$ & $\mathbf{p}$ \\
\hline Considerably & 1 & 13.50 & 3 & \multirow{2}{*}{6.852} & \multirow{2}{*}{.077} \\
\hline Properly & 10 & 15.85 & & & \\
\hline Barely & 12 & 9.67 & & & \\
\hline Never & 3 & 21.00 & & & \\
\hline
\end{tabular}


3.1.10 Comparison of the Participants' Posttest Scores on the Attitude Scale by to What Extent a Nearby Located National Park Is Cared About

Table 16. The results of the Kruskal-Wallis test for the participants' posttest scores on the attitude scale by to what extent a nearby located national park is cared about

\begin{tabular}{|c|c|c|c|c|c|c|}
\hline $\begin{array}{l}\text { Caring about a nearby } \\
\text { located national park }\end{array}$ & $\mathbf{N}$ & Mean rank & DF & $\chi^{2}$ & $\mathbf{p}$ & Significant Difference \\
\hline Considerably & 1 & 15.00 & 3 & \multirow{2}{*}{10.134} & \multirow{2}{*}{.017} & \multirow{3}{*}{ Properly-Barely } \\
\hline Properly & 10 & 18.65 & & & & \\
\hline Barely & 12 & 8.46 & & & & \\
\hline Never & 3 & 16.00 & & & & \\
\hline
\end{tabular}

The participants had different views on to what extent a nearby located national park is cared about. Table 16 presents the results of the Kruskal-Wallis test for the prospective teachers' posttest scores on the Attitude Towards National Parks Scale by their such views.

The results showed that the participants' posttest scores on the attitude scale differed significantly by their above-mentioned views, $\chi^{2}(\mathrm{SD}=3, \mathrm{n}=26)=10,134, \mathrm{p}<.05$. Considering the mean ranks of their views, it was discovered that the most frequent response was "Properly" after the practice education, and it was followed by the responses "Never," "Considerably," and "Barely." Binary comparisons were made among the groups with the Mann-Whitney $U$ test, and the significant difference was found between the responses "Properly" and "Barely" in favor of "Properly."

\subsection{Findings Regarding the Second Research Question}

\subsubsection{What Is Your Reason for Attending the Ecology-Based Environmental Education?}

The analysis of the responses given to the first question in the interview form, "What is your reason for attending the ecology-based environmental education?" revealed 7 different themes. The themes emerged and participants' views are as follows:

a. Curiosity (R1, R5, R6, R7, R8, R10, R13, R16, R22, and R24)

R1: Because I want to see it closely; I'm curious about it.

R5: To travel, to discover, and to see the pure form of nature.

R6: To discover the beauties in nature and to be in touch with nature.

R7: To know plants and animals that we don't know.

R8: To take my admiration for the environment and nature to further.

R10: I have a curiosity about ancient settlements and love animals. 


\section{Macrothink

R13: I spent my childhood in villages; I had a chance to discover the natural environment, and I'm always curious about nature. This is the reason why I want to attend this practice.

R16: To see and explore new places and to tell about them in the future.

R22: To see different animal and plant species there.

R24: Because I haven't visited such areas in Antalya and I have previously assumed that it is enough just to know it theoretically.

\section{b. Peace (R1, R9, R10, R14, R17, R19, and R25)}

R1: Places like here give me peace.

R9: I like to be in touch with nature.

R10: Being in touch with nature makes me happy.

R14: To have a nice day by relaxing my mind.

R17: It is very peaceful to live in harmony with nature even for a few hours, away from the noise of the city and car exhausts.

R19: Since it is a place where we can discover our history away from the chaos of the city.

R25: To see different plants in nature and to get away from today's concrete jungle.

\section{c. To be knowledgeable (R1, R3, R4, R5, R8, R14, R18, R20, R21, R23, and R26)}

R1: I also think I will be knowledgeable.

R3: To get to know the environment better and to know about plant and animal species.

R4: I would also like to get to know about my study field more.

R5: I think it will contribute to me since my study field also covers such education, and I like to visit, see, and know about such places.

R8: I attend this practice education to get to know the places I haven't seen before, to learn something about them, and to be accultured.

R14: I would like to be conscious of the balance of nature.

R18: To get to know more about the plant and animal species around.

R20: To get to know nature better and to see our natural heritage.

R21: To better understand our past and to improve myself.

R23: To be knowledgeable about the subject, and to learn what can be done to protect nature. R26: To be knowledgeable about the subject. 


\section{d. To increase sensitivity (R2, R11, and R26)}

R2: I love nature. I think it should be protected. I want to be a more sensitive person thanks to this environmental education.

R11: To form a full consciousness of nature.

R26: To gain nature awareness.

\section{e. Love of nature (R2, R4, R9, R13, and R17)}

R2: I love nature.

R4: I'm a nature lover.

R9: I like to be in touch with nature.

R13: Above all, I'm a nature lover.

R17: I love nature.

\section{f. Not loving nature (R12,)}

R12: I don't love nature.

\section{g. $N / A(R 15)$}

R15: I haven't attended the practice education.

3.2.2 Where and How Do You Intend to Use the Knowledge You Have Acquired in the Practice Ecology-Based Environmental Education?

The analysis of the responses given to the second question in the interview form, "Where and how do you intend to use the knowledge you have acquired in the practice ecology-based environmental education?" revealed 5 different themes. The themes emerged and participants' views are as follows:

a. To share the knowledge and experiences with people around me $(R 1, R 2, R 6, R 7, R 8$, $R 11, R 15, R 17, R 19, R 20, R 22$, and R24)

R1: I intend to convey the knowledge I have gained to the people around me and to ensure that they are also knowledgeable. So, they will be curious about and go to see it.

R2: Above all, I want to share the knowledge with my acquaintances.

R6: I want my acquaintances to be knowledgeable by telling them what I have learned.

R7: I would like to increase my general knowledge level a little higher and to tell what I have learned here to my family and friends to increase their awareness.

R8: First of all, I will inform my friends and let them see such beautiful and rare places. Then, I will try to raise awareness and consciousness among people not to pollute nature. 
R11: When I return to my hometown, I intend to share the beauties here with every person I meet, and I will try to convey what I have learned to let them gain nature consciousness.

R15: It can be used to raise public awareness. Thus, a conscious generation will have been raised.

R17: I want to convey it to my family and raise their awareness.

R19: It can contribute to my general knowledge, and I can raise others' awareness.

R20: When I'm asked about national parks, I can tell people about here and convey my observations.

R21: To accurately explain what I have learned and to make people know about the past.

R24: I can use it in terms of general knowledge and introducing such places to foreigners who don't know the beauties of our country.

\section{b. To raise students more conscious $(R 3, R 4, R 5, R 10, R 16, R 18$, and $R 25)$}

R3: After graduation and being employed as a teacher, I will use it to raise my students as more conscious individuals and to convey the knowledge to them.

R4: I think that learning by traveling and seeing will be more permanent. In this way, I hope that I will convey the knowledge I have gained to my students more effectively in my professional life.

R5: I think I will benefit from it because it is related to my study field. In this way, I will collect memories that I will remember all the time. I will have the opportunity to convey it to others. I will tell my children and students in the future.

R10: When I become a teacher, I will share my knowledge with my students.

R16: I think of sharing it with people around me, but rather I want to convey it to students when I become a teacher.

R18: I think of using it to inform my family and the people around me to encourage them to visit such places. I want to convey it to them by visiting national parks with them when I become a teacher in the future.

R25: I think of telling it to the people I'm in contact with, and I want to use it to be able to respond to the questions on this subject when I become a teacher.

\section{c. To gain protection awareness of natural beauties around me (R9 and R14)}

R9: I think I need to protect natural beauties around.

R14: I can use it to correct what is known wrong, to warn those doing wrong about nature, and to raise awareness among my friends.

\section{d. No idea (R12)}

R12: I don’t know. 


\section{e. To use it in daily life $(R 13, R 23$, and $R 26)$}

R13: I can use it in my daily life. Human life is already intertwined with nature, so that I can use it in many domains of my life.

R23: I think the knowledge I have gained will guide me for the rest of my life.

R26: In-class environment or daily life.

\subsection{Findings Regarding the Third Research Question}

The following findings were reached by performing the content analysis on the data obtained from the interviews with the participants following the "Practice Ecology-based Environmental Education."

\subsubsection{What Is Your Reason for Attending the Ecology-Based Environmental Education?}

The analysis of the responses given to the first question in the interview form, "What is your reason for attending the ecology-based environmental education?," revealed 4 different themes. It was found out that 3 themes emerged prior to the practice education (peace, not loving nature, and not attended) were not uttered by the participants after the practice. The themes emerged and participants' views are as follows:

\section{a. Curiosity (R1, R5, R8, R9, R10, R12, R13, R16, R19, and R24)}

R1: Because I love nature and I'm curious about it.

R5: I would like to attend such events to visit new places, to interact with new people, and to learn something new.

R8: To get to know my environment better and to see the natural beauties around me.

R9: To get to know nature and to see historical beauties. To discover what kind of beauties are around me.

R10: I have always wondered about and had an interest in such environments.

R12: Because I'm curious about it.

R13: It is a place I haven't been to before. I have attended the practice because of a bit of curiosity and interest.

R16: I have attended it to see the historical beauties and plant and animal species in the national park.

R24: I have wanted to see nature with the naked eye.

\section{b. To be knowledgeable (R2, R3, R4, R5, R7, R11, R14, R15, R17, R20, and R22)}

R2: I love nature, and I intend to increase my knowledge and become a more sensitive person through this practice education.

R3: Getting to know my environment and animals and plants around better. 
R4: I want to know more about nature.

R5: To visit new places and to interact with new people. I would also like to attend such events to be knowledgeable.

R7: To be knowledgeable about ecological being that I don't know in my environment.

R11: To get to know nature better.

R14: To know nature better. To grasp the importance of historical places.

R15: To do practice education and to see the riches of nature.

R17: I have wanted to get to know nature and to be knowledgeable about plants. It has beeb very enriching.

R20: To get to know nature better and to have knowledge about such beauties of nature.

R21: To be better aware of the national park in the city where I live and to improve myself by learning from instructors who have proven expertise in their fields.

R22: Project.

R23: To be knowledgeable about nature and to know more about it.

c. To increase sensitivity (R2, R18, and R26)

R18: To know our environment better and to live with increased sensitivity to what I see around from now on.

R26: To know and protect nature and to gain lifelong awareness about it.

\section{d. Love of nature (R1, R2, R6, and R25)}

R1: Because I love nature; I'm curious about it.

R6: I have wanted to discover natural beauties around me.

R25: To be in touch with nature.

3.3.2 Where and How Do You Intend to Use the Knowledge You Have Acquired in the Practice Ecology-Based Environmental Education?

The analysis of the responses given to the second question in the interview form, "Where and how do you intend to use the knowledge you have acquired in the practice ecology-based environmental education?," revealed 3 different themes. The themes emerged and participants' views are as follows:

a. To share the knowledge and experiences with people around me $(R 1, R 2, R 8, R 11, R 12$, R14, R15, R17, R19, and R24)

R1: I intend to convey the knowledge I have gained to those around me.

R2: I would like to inform my acquaintances about environmental education. 
R8: I can share what I have seen and learned with people around me and encourage them to see such beauties.

R11: To share it with my siblings, and then with the people around me.

R12: I intend to share it with my friends in the dorm.

R14: To my friends and acquaintances.

R15: It can be used to raise public awareness.

R17: First, I have shared it with the people around me.

R19: I have been knowledgeable about plants, and I can share it with those around me.

R24: I think of informing people and conveying my experiences to someone else.

\section{b. To raise students more conscious $(R 3, R 5, R 6, R 7, R 10, R 16, R 18, R 20, R 23$, and $R 25)$}

R3: I will better inform my students about nature in the future. I will raise environmentally conscious students.

R5: When I become a teacher, I intend to use it while teaching about nature to my students and while informing and encouraging people around me. I also intend to use it in photography.

R6: I have gained enriching knowledge that I will share with my students and relatives in the future.

R7: I intend to use it when I become a teacher or to inform people around me now.

R10: I advise my acquaintances to visit such places. I will convey the knowledge I have acquired to my students in the future.

R16: I think I can guide my friends who want to visit national parks and that I can convey the knowledge I have gained to the students when I become a teacher.

R18: When I become a teacher in the future, I intend to share it with my students and other children.

R20: In the future, I want to convey the knowledge I have acquired to my students.

R23: I can use it when I become a teacher in the future.

R25: I will teach my students by giving examples from my own life, not from the book.

\section{c. To use it in daily life (R4, R9, R13, R21, R22, and R26)}

R4: I think I will be more conscious both in my daily life and while teaching my students.

R9: I can use it when I spend time in nature. I want to share what I have learned with my family and friends when we go to forests, parks, and mountains.

R21: I think of using what I have learned by enriching it. 
R22: I think of using it in my daily life.

R26: In social life.

\section{Discussion and Conclusion}

The results of the normality tests prior to the primary statistical analyses showed that the prospective teachers' pretest and posttest scores on the attitude scale did not distribute normally. Therefore, non-parametric statistical analysis techniques were utilized in the study.

It was determined that the participants had gone to a national park for only picnic purposes before this study. This finding coincides with the finding of Deniş and Genç (2010) that the majority of the eighth-grade students had visited a national park for a picnic.

Shaft and Sharfman (1997) argue that when individuals' attitudes towards any object are clearly understood, then, their behaviors and preferences towards that object can also be predicted. According to the findings obtained by Borchers, Boesch, Riedel, Guilahoux, Ouattara, and Randler (2014), after an extracurricular environmental education program applied to elementary school students, the knowledge and attitudes of male students towards environment increased positively compared to their female counterparts, and they gained more from the program. Contrary to such a finding, it was found that the prospective teachers' pretest and posttest scores on the "Attitude Towards National Parks Scale" did not differ significantly by gender.

It was also found out that the prospective teachers' pretest and posttest scores on the attitude scale did not differ significantly by teaching field (social sciences or elementary education).

Prospective social studies teachers' pretest and posttest scores on the "Attitude Towards National Parks" were found not to differ, and it was also the case for the scores of prospective elementary education teachers. These results of the study are also in line with the result of a master's thesis study, in which Karakaş (2010) concluded that teachers' attitudes towards a nearby located national park did not differ by their teaching fields and gender.

It was concluded that the prospective teachers' pretest and posttest scores on the "Attitude Towards National Parks Scale" did not differ significantly by whether to visit a national park before. Overall, this result contrasts with Deniş and Genç's (2010) finding that the attitudes of the eighth-grade students living around national parks differed significantly from the attitudes of those who had never been to a national park before.

It was discovered that the prospective teachers' pretest scores on the attitude scale did not differ significantly by to what extent a nearby located national park is cared about while their posttest scores significantly differed. It was revealed that the significant difference was between the responses "Properly" and "Barely" in favor of "Properly." In a study conducted on the attitudes of local people living around the Mt. Elgon National Park towards protection education and national parks, Oonyu (2009) concluded that more than three-quarters of the participants cared about the national park and had positive attitudes towards the protection of that national park. This result is in line with the above-mentioned finding of the present research. In her study, where the effects of ecology-based environmental education were 
sought on teachers' views on environmental education, Güler (2009) suggested that the participants stated that they became more responsible regarding environmental education and discovered that there were many activities they would like to do with their students at the end of the practice education. These findings also support the qualitative findings of this study. Finally, Tubb (2003) reported that the attitude scores of the national park visitors differed positively according to the surveys administered to visitors before and after the visit to the park.

Environmental classes taught in faculties of education can be made in nearby located national parks. In this way, prospective teachers can ensure environmentally sensitive, meaningful, and permanent learning by living and observation. This study was carried out on a small group of prospective social studies and elementary education teachers. Similar studies can be conducted with prospective teachers enrolled in different departments and with larger groups of samples.

\section{References}

Atalay, İ. (2004). Doga bilimleri sozlugu. İzmir: Meta Basım Matbaacılık.

Atasoy, E. (2006). Cevre için eğitim çocuk doğa etkileşimi. Bursa: Ezgi Kitabevi.

Atik, M., \& Tokgöz, A. (2005). Korumada çevre eğitimi (pp. 73-82). Korumada 50 y1l Sempozyumu, Mimar Sinan Güzel Sanatlar University, 17-18 Nov., 2005, İstanbul.

Ayvaz Öztürk, S. (2019). Investigation of environmental sensitivity of social sciences associate students. Journal of Innovative Research in Social Studies, 2(1), 71-79.

Bodnar, R. (2004). The effect of the tourism of the Hortobagy National Park on the surrounding settlements, lesson of a questionnaire survey. Working papers of the Finnish forest Research Institute.

Borchers, C., Boesch, C., Riedel, J., Guilahoux, H., Ouattara, D., \& Randler, C. (2014). Environmental education in Côte d'Ivoire/West Africa: Extra-curricular primary school teaching shows positive impact on environmental knowledge and attitudes. International Journal of Science Education, Part B, 4(3), 240-259 https://doi.org/10.1080/21548455. 2013.803632

Buldur, S., \& Doğan, A. (2017). The effects of formative assessment process via performance-based techniques on student's achievement goal-orientations. Hacettepe University Journal of Education, 32(1), 143-167. https://doi.org/10.16986/HUJE.2016015694

Çepel, N. (1992). Doga çevre ve ekoloji ve insanlıgın ekolojik sorunları. İstanbul: Altın Kitaplar Yayınevi.

Çepel, N. (2003). Ekolojik sorunlar ve çözümleri (2nd ed.). Ankara: Tübitak Popüler Bilim Kitapları.

Davis, J. (1998). Young children, environmental education, and the future. Early Childhood Education Journal, 26(2), 117-123. https://doi.org/10.1023/A:1022911631454 
Demirel, Ö., Sarıkoç, E., Özdemir, B., \& Pirselimoğlu, Z. (2005). Problems relating protected areas (National Parks) In Turkey and the new protected area approach (pp. 71-80). Korunan Doğal Alanlar Symposium, Proceedings Book, 8-10 Sept., 2005, Isparta.

Demirkaya, H. (2006). The place of environmental education in geography curricula in Turkey and new approaches to enironmental education. Firat University Journal of Social Sciences, 16(1), 207-222.

Demirkaya, H., \& Ünal, O. (2018). In Ş. Çınkır (Ed.), Sosyal bilgiler öğretmen adaylarının çevre bilinci ve çevre duyarlılıklarının incelenmesi (pp. 276-286). EJER Congress 2018 Conference Proceedings ... Içinde. Antalya.

Deniş, H. (2007). Investigating 8th class students' attitudes towards the national parks in their immediate environment (The case of Isparta province) (Master's thesis, Süleyman Demirel University, Fen Bilimleri Enstitüsü, Isparta).

Deniş, H., \& Genç, H. (2010). Investigating 8th class students' attitudes towards the national parks in their immediate environment into the same variables (the case of Isparta province). The Journal of Graduate School of Natural and Applied Sciences of Mehmet Akif Ersoy University, 1, 9-25.

Deniş, H., Genç, H., \& Demirkaya, H. (2008). Development an attitude scale to measure attitudes toward national park. Journal of Gazi Educational Faculty, 28(2), 95-107.

Erol, G. H., \& Gezer, K. (2006). Prospective elementary school teachers' attitudes towared environment and environmental problems. International Journal of Environmental and Science Education, 1(1), 65-77.

Genç, H., Demirkaya, H., \& Karasakal, G. (2010). Primary school students' opinions about forest: A qualitative study. The Journal of Graduate School Natural and Applied Sciences of Mehmet Akif Ersoy University, 2, 150-166.

Genç, H., Demirkaya, H., \& Karasakal, G. (2010). Seventh grade primary school students' understanding of forest: A phenomenographic study. The Journal of Graduate School Natural and Applied Sciences of Mehmet Akif Ersoy University, 1, 34-48.

Güler, T. (2007). Yaygın eğitimde çevre eğitimi. İçinde: "Çevre Eğitimi”" Türkiye Çevre Vakfı Yayını (No: 178, pp. 99-116). Ankara, Turkey.

Güler, T. (2009). The effects of an ecology based environmental education on teachers' opinions about environmental education. Education and Science, 34(151), 30-43.

Karakaş, A. (2010). Research of the teachers' attitudes about the national parks in their surrounding (the case of Isparta and Denizli provinces) (Master's thesis, Mehmet Akif Ersoy University, Burdur).

Köksal, A. E. (2005). Informal learning environments: Participants views of learning and teaching environmental education in National Parks (pp. 45-47). Korunan Doğal Alanlar Sempozyumu, 8-10, Symposium Proceedings Book, Isparta. 


\section{Macrothink

Kuvan, Y. (2005). The importance and assessment of the effectiveness in protected area management, Sözlü Bildiriler Kitabı, 81-89.

Lam, M. L. (2004). A study of stated attitudes and behaviour of local people toward conservation in Koshi Tappu Wildlife Reserve, Nepal. 15th Biennial Conference of the Asian Studies Association of Australia in Canberra 29th June-Second July.

Malone, K., \& Tranter, P. (2003). Children's environmental learning and the use, design and management of school grounds. Children, Youth and Environments, 13(2), 1-30.

Merriam-Webster Online. (2018). In Merriam-Webster. Retrieved March 10, 2018, from http://www.merriam-webster.com/dictionary/citation

Miles, M. B., \& Huberman, A. M. (2004). An expanded sourcebook qualitative data analysis (2nd ed.). USA: Sage Production.

Oonyu, J. C. (2009). Conservation education and the attitudes of local communities living adjacent to Mt. Elgon National Park, Uganda. Applied Environmental Education and Communication, 8(3-4), 153-164, https://doi.org/10.1080/15330150903269258

Ozaner, F. S. (2004). Türkiye'de okul dışı çevre eğitimi ne durumda ve neler yapılmalı? (pp. 67-98). V. Ulusal Ekoloji ve Çevre Kongresi, 5-8 October 2004, Taksim International Abant Palace, Abant İzzet Baysal University \& Biyologlar Derneği, Abant-Bolu. Bildiri Kitab1 (Doğa ve Çevre), Biyologlar Derneği, İzmir.

Resmi Gazete. (2003). Çevre ve Orman Bakanlı̆̆ Teşkilat ve Görevleri Hakkında Kanun (25012 say1).

Shaft, T., \& Scharfman, M. A. (1997). Confirmatory Factor Analysis of The Attitude Toward Computer Instrument (ATCI). Retrieved June 21, 2019, from http://hsb.baylor.edu/ramsower/ ais.ac.97/papers/shaft.htm

Sönmez, V., \& Alacapınar, F. G. (2011). Örneklendirilmiş bilimsel araştırma yöntemleri. Ankara: Anı Yayıncılık.

Tabachnick, B., \& Fidell, L. S. (2015). Çok değişkenli istatistiklerin kullanımı. Ankara: Nobel Akademik Yayıncılık.

Thoe, N. K., \& Lin, C. S. (2006). Integrating learning together with outdoor science activities. Learning Science \& Mathematics. Retrieved March 16, 2018, from http://www.recsam.edu. my/lsm/2006/2006_5_NKT.pdf

Tubb, N. K. (2003). An evaluation of the effectiveness of interpretation within Dartmoor National Park in reaching the goals of sustainable tourism development. Journal of Sustainable Tourism, 11(6), 476-498. https://doi.org/10.1080/09669580308667217

Yalınkılıç, M. K., \& Yenilmez Arpa, N. (2005). Ecotourism and the protected areas in Turkey (pp. 3-13). Korunan Doğal Alanlar Sempozyumu, Sözlü Bildiriler Kitab1, 8-10 Sept., 2005, Isparta. 


\section{Copyright Disclaimer}

Copyright for this article is retained by the author(s), with first publication rights granted to the journal.

This is an open-access article distributed under the terms and conditions of the Creative Commons Attribution license (http://creativecommons.org/licenses/by/3.0/). 